mainly for the proposal and not the past, this is not a severe problem. Competence in the area could be accomplished by reference to the applicant's work in the group publication (for example, RNA Polymerase, 5, 65). Perhaps a less competitive environment would also encourage scientists to worry more about the tendency to a concentration of an increasing fraction of the financial resources for science under the direct control of a few people. University promotion committees would also have to be familiar with the system.

Three alternatives follow, which would in my view be less effective. One of the possibilities is for a group meeting as above, but with individual papers signed as in a typical current symposium.

The race into print would be eliminated, but personal contributions would be documented. My third suggestion is that certain issues (perhaps two per year) of standard journals should be devoted to a particular research interest. This fact would be advertised well in advance, papers would be collected and published together with an introduction and summary (signed) by members of the editorial board of the journal. This should improve communication with other fields and might lessen competition without the technical problems of an organized meeting and book publication. However, the research group would retain less control over its summarizers and the general publishing policy. Yet another possibility is an informal agreement that people would actively arrange with others working along similar lines to publish simultaneously or jointly and to try to minimize duplication. (This is, of course, sometimes done at present.)

Yours faithfully,

HARRISON ECHOLS

Department of Molecular Biology,

University of California,

Berkeley, California 94720

\section{Science Libraries}

SIR,--Sandison (Nature, 234, 368; 1971) has cast doubt on the accuracy of Brookes' (Nature, 232, 458; 1971) model for optimizing a library of scientific periodicals on the grounds that the members of the Bradford set are not constant and that rank within the Bradford set changes with time. base year are taken into account in the optimization process.

With $100 \%$ target percentage all error in the model is due to papers in newly contributing periodicals. The percentage error due to this cause is approximately the same all through the target range of interest. This allows the calculation of an expected percentage of papers in the library in 1940 allowing for periodicals

Table 1 Percentage of Relevant Papers in the Library in 1940 for Various Target Percentages Set by the Bradford Cut in Various Base Years

\begin{tabular}{|c|c|c|c|c|c|c|}
\hline Base year & \multicolumn{3}{|c|}{$\begin{array}{l}\text { Percentage papers in library } \\
\text { in } 1940 \text { for target } \% x \\
x=50 \quad x=75 \quad x=100\end{array}$} & \multicolumn{2}{|c|}{$\begin{array}{l}\text { Expected \% papers in library } \\
\text { in } 1940 \text { taking into account } \\
\text { new contributing periodicals } \\
\text { for target } \% x\end{array}$} & $\begin{array}{l}\text { No. of contributing } \\
\text { periodicals in } \\
\text { base year }\end{array}$ \\
\hline $\begin{array}{l}1925 \\
1930 \\
1935\end{array}$ & $\begin{array}{l}15 \\
29 \\
40\end{array}$ & $\begin{array}{l}25 \\
44 \\
57\end{array}$ & $\begin{array}{l}38 \\
61 \\
77\end{array}$ & $\begin{array}{l}19 \\
30 \\
38\end{array}$ & $\begin{array}{l}29 \\
46 \\
58\end{array}$ & $\begin{array}{r}39 \\
96 \\
190\end{array}$ \\
\hline $\begin{array}{l}1925 * \\
1930 * \\
1935 *\end{array}$ & $\begin{array}{l}26 \\
33 \\
40\end{array}$ & $\begin{array}{l}44 \\
54 \\
72\end{array}$ & $\begin{array}{l}59 \\
77 \\
91\end{array}$ & $\begin{array}{l}30 \\
39 \\
46\end{array}$ & $\begin{array}{l}44 \\
58 \\
68\end{array}$ & $\begin{array}{l}166 \\
284 \\
471\end{array}$ \\
\hline
\end{tabular}

* Optimization process based on cumulated experience to base year by using all papers published up to and including base year for ranking periodicals.

An estimate of these errors can be obtained from Needhams' bibliography (Biochemistry and Morphogenesis, Cambridge University Press, 1942) which can be considered an approximation to a complete set of papers relating to the biochemistry of morphogenesis up to 1940. This bibliography is appended to a comprehensive review of the subject and contains 6,668 references to papers in periodicals. It conforms with Bradford's law and the negative exponential distribution of papers with time.

If a librarian has optimized his library by Brookes' Bradford cut in 1925, 1930 and 1935 with the object of providing $50 \%, 75 \%$ or $100 \%$ of papers, the actual percentage that would have been in the library in 1940 is shown in Table 1. It also shows the percentage in the library when all papers up to and including the that begin contributing after optimization (Table 1).

The difference between the expected percentage and the actual percentage represents error due to change in the ranking of periodicals. If the ten most productive periodicals for the years 1925 , 1930, 1935 and 1940 are listed each title appears on average 1.6 times. Despite this change in ranking, the error due to this change is small by comparison with error due to new contributing periodicals. For an expanding literature such as the one studied, review of the Bradford set must be more frequent than every five years if Brookes' model is to yield acceptable predictions.

Yours faithfully, I. A. Douglas

Newcastle Public Library, Newcastle, New South Wales

\title{
Obituary
}

\section{Dr P. H. Leslie}

THE death, in June of this year at the age of 72 , of Patrick Holt Leslie has deprived the world of ecological science of one of its most brilliant biomathematicians, one to be ranked with Raymond Pearl and Alfred Lotka. Educated at Westminster School and Christ Church, Oxford, he obtained an honours degree in physiology in 1921, but was later prevented by a very serious illness of the lung from completing a medical course. After several years of research in bacteriology at the School of Pathology in Oxford, he began an association with the Bureau of Animal Population (under Charles Elton as Director) that continued from 1935 to his retirement in 1967. $\mathrm{He}$ became a Senior Research Officer there and his activities fell into two closely-related spheres: advisory work on statistical matters, and his own research upon demographic methods and problems. Leslie (known to his family and a large circle of friends as "George") was compelled by his earlier ill-health to live a quiet and somewhat secluded life. His habit was to visit the laboratory in the morning to advise and read, but to spend the rest of his time working at home. Thus, like Darwin and unlike many in the academic hurly-burly of today, he had uninterrupted opportunities to think, analyse and calculate. Through these years he was greatly helped by the devoted care of his wife. It is to be noted with some astonishment that Leslie had no formal training in advanced mathematics, and his extra- 


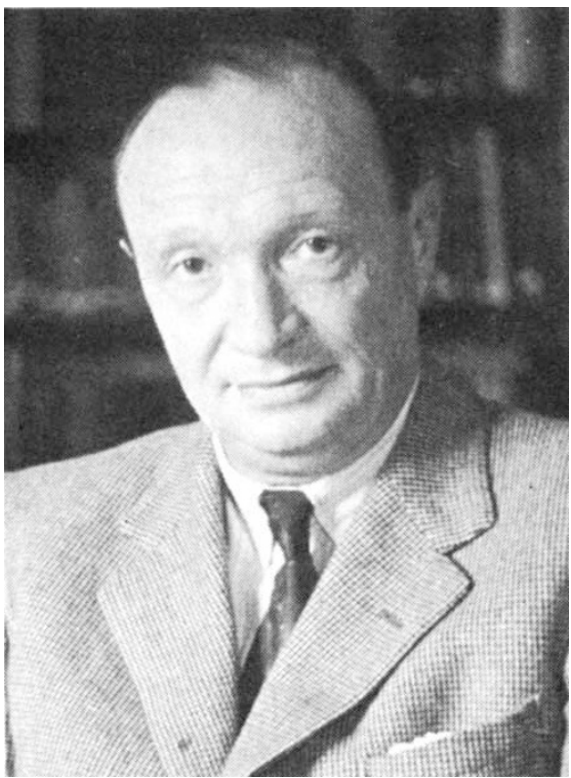

ordinary talent for original mathematical approaches to ecological problems became apparent unusually late, after the age of 35 . He came to be held in high respect by more professionally trained experts in the same field. Hundreds of research workers at the bureau and elsewhere are in his debt for shrewd and patient advice, often also for much careful examination and computation of their figures. His tall figure, quiet manner, friendliness to people of all ages, whimsical humour, and incisive intellectual powers became, so to speak, an institution within the research institute. On matters of scientific integrity he was adamant, and many young and some older research workers gained their first statistical training from him. But the advisory aspect of his activities was also important for the development of Leslie's own ideas; for he attained a clear picture of the kind of assumptions that ecologists deal with, the long and tedious and usually incomplete nature of field studies on animal populations, and their sampling problems. Thus his own ideas always started from sound ecological premises.

Leslie's first original work on populations was the calculation of the intrinsic or natural rate of increase of a wild animal, using data for voles, Microtus agrestis, bred in the laboratory by R. M. Ranson. This calculation employed age-specific rates for births and deaths. Such an estimate had previously been made only for man, those for animals being fallacious guesses based upon reproductive capacity alone. Later he calculated such rates also for the brown rat, the Orkney vole and flour-beetles. The methods were quite novel for animal ecology. He went on to much more complex theoretical studies of population growth and structure (including age-distribution and generation time) and of the interactions between species. His paper "On the use of matrices in certain population mathematics" (1945) is a classical one. During the Second World War he used his skills in the bureau's team research upon the control of harmful rodent populations. In his later years he took up two chief subjects. First, the statistical basis of marking and recapturing live-trapped small rodents (but applicable much more widely) to yield population data, using the field operations of Dennis and Helen Chitty on voles. Secondly, he began a long and brilliant series of studies upon the application of stochastic equations, as compared with the more simplified deterministic types, to the elucidation of predator-prey and inter-species relations. Much of this was made possible by the programming help of J. C. Gower on the Rothamsted computer. From 1948 onwards, Leslie formed an increasingly close association with Thomas Park of the Department of Zoology in the University of Chicago, who had for many years engaged in laboratory experiments upon competition between two species of flour-beetles (Tribolium). Gradually he was able to develop equations that simulated and illuminated the very complex results of some of these experiments. His whole self-made mathematical career, with its cometlike character, must have done much to make people realize the formidable complexities inherent in population ecology, and has provided valuable new tools for use in them. He gained his Oxford DSc on the published results of his various researches.

\section{Reports and Publications}

not included in the Monthly Books Supplement

\section{Other Countries}

Fisheries Research Board of Canada. Technical Report No. 318: Distribution, Relative Abundance and Growth of Larval Herring Clupea harengus $\mathrm{L}$. in the Southern Gulf of St. Lawrence. By $\mathbf{S}$. N

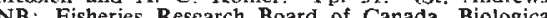
NB: Fisheries Rescarch Board of Canada, Biological Geon, 1972. Survey of Canada. Miscellaneous 22 port No 17: Laboratories, Scientific and Technical port No. 17: Laboratories, Scientific and Technical laneous Report No 18: Harker. Pp. 42. Miscel ianeous Report No. 18: The Geological Survey of By S. C. Robinson. Pp. 26. Paper 71-9: Relationships of Structural Lineaments and Mineral Occurrences in the Abitibi Area of the Canadian Shield. By Jan Kutina and Andrea Fabbri. Pp. viiit 36 . \$2 Ottawa: Information Canada, 1972.) US Department of the Interior: Geological Survey Water-Supply Paper 1939-C: Electrical-Analo Analysis of the Hydrologic System. Tucson Basin, South-eastern Arizona. By T. W. Anderson. Pp iv t $34+6$ plates. (Washington, DC: Government Printing Office, 1972.) US Department of Agriculture: Agricuitural Research Servic: Marketing Research Report No. 482 Hypobaric Storage of Mature-Green Tomatoes. By Prin. Tolle. 15 ing.

\section{HOW TO BUY NATURE}

Volumes start in January, March, May, July, September and November, but subscriptions may begin at any time.

The direct postal price per subscription is :

12 MONTHS * (52 issues per title)

\begin{tabular}{|c|c|c|}
\hline & $\begin{array}{l}\text { Surface mail } \\
\text { UK and } \\
\text { worldwide }\end{array}$ & $\begin{array}{l}\text { U.S.A. and } \\
\text { Canada }\end{array}$ \\
\hline Nature (Friday) & $£ 14$ & $\$ 48$ \\
\hline $\begin{array}{l}\text { Nature }+ \\
\text { Nature Physical Science }\end{array}$ & $£ 24$ & $\$ 83$ \\
\hline $\begin{array}{l}\text { Nature }+ \\
\text { Nature New Biology }\end{array}$ & $£ 24$ & $\$ 83$ \\
\hline All three editions & $£ 29.50$ & $\$ 108$ \\
\hline Annual Index & $£ 1$ & $\$ 3$ \\
\hline
\end{tabular}

* Rates for shorter periods pro rata (minimum three months)

(Charge for delivery by air mail on application)

\section{Editorial, Advertising and Publishing Offices of NATURE}

MACMILLAN JOURNALS LIMITED 4 LITTLE ESSEX STREET, LONDON WC2R 3LF

Telephone Number: 01-836 6633. Telegrams: Phusis London WC2R 3LF Telex 262024

MACMILLAN JOURNALS LIMITED

711 NATIONAL PRESS BUILDING

WASHINGTON DC 20004

Telephone Number : 202-737 2355. Telex 64280

International Advertisement Manager PETER R. KAVANAGH

Telephone Number. UK 01-836 6633 USA 202-737 2355 Subscription Department

MACMILLAN JOURNALS LIMITED

BRUNEL ROAD, BASINGSTOKE, HANTS Telephone Number: Basingstoke 29242

Subscription Department

MACMILLAN JOURNALS LIMITED

BRUNEL ROAD, BASINGSTOKE, HANTS

Telephone Number: Basingstoke 29242 Classified advertisements

T. G SCOTT \& SON, LIMITED

1 CLEMENT'S INN. LONDON WC2A 2ED

Telephone: 01-242 6264/01-405 4743

Telegrams: Textualist London WC2A 2ED

Registered as a newspaper at the Post Office

Copyright (C) Macmillan Journals Limited, October 201972 